SHORT COMMUNICATION

\title{
First phytochemical description of essential oils from Piper cachimboense (Piperales, Piperaceae)
}

\author{
Diones KRINSKI ${ }^{1 *}$, Luís Amilton FOERSTER², Cicero DESCHAMPS² \\ ' Universidade do Estado de Mato Grosso, Departamento de Ciências Biológicas, Campus Universitário de Tangará da Serra, Caixa Postal 287, Jardim Aeroporto, CEP \\ 78300-000 Tangará da Serra, MT, Brasil \\ 2 Universidade Federal do Paraná, Departamento de Fitotecnia e Fitossanitarismo, Caixa Postal 19061, CEP 80035-050, Curitiba, PR, Brasil \\ * Corresponding author: diones.krinski@unemat.br
}

\section{ABSTRACT}

Piper cachimboense is recorded only for the Amazon region of Brazil and Colombia, and the objective of this study was to report the first phytochemical assessment of the composition of the essential oils (EOs) from this species collected in the Amazon rainforest, in Novo Progresso, Pará State, Brazil. Samples of leaves were subjected to hydrodistillation in a Clevenger-type apparatus. The chemical identification was carried out by gas chromatography. The yield of oils was of $11.03 \pm 5.94 \%$ for fresh leaves, and $1.07 \pm 0.27 \%$ for dry leaves. The analysis showed 36 volatile compounds from fresh leaves and 49 from dried leaves. Main constituents in EOs of both fresh and dried leaves from P. cachimboense were (E)-caryophyllene, germacrene-D, $\gamma$-amorfene, $\delta$-cadinene and apiole.

KEYWORDS: safrole, (E)-caryophyllene, germacrene-D, spathulenol, dillapiole

\section{Primeira descrição fitoquímica de óleos essenciais de Piper cachimboense (Piperales, Piperaceae)}

\section{RESUMO}

Piper cachimboense é registrada apenas para a região amazônica do Brasil e Colômbia, e o objetivo deste estudo foi relatar, pela primeira vez, a composição fitoquímica dos óleos essenciais (OEs) desta espécie coletada na floresta amazônica, em Novo Progresso/PA, Brasil. Amostras de folhas foram submetidas a hidrodestilação em aparelho tipo Clevenger. A identificação química foi realizada por cromatografia gasosa e o rendimento dos óleos foi de 11,03 $\pm 5,94 \%$ para as folhas frescas e de 1,07 $\pm 0,27 \%$ para as folhas secas. A análise mostrou 36 compostos voláteis para folhas frescas e 49 para folhas secas. Os constituintes principais dos OEs de folhas frescas e secas de $P$. cachimboense foram $(E)$-cariofileno, germacreno-D, $\gamma$-amorfeno, $\delta$-cadineno e apiol.

PALAVRAS-CHAVE: safrol, $(E)$-cariofileno, germacreno-D, espatulenol, dilapiol 
Piperaceae Giseke, 1792, is a family of tropical and subtropical plants which occur in both hemispheres, including about 3,500 species, and the Piper genus is the largest, with more than 700 species, of which about 285 grow natively in Brazil and 192 are considered endemic (Monteiro and Guimarães 2009; Guimarães and Carvalho-Silva 2012).

Essential oils (EOs) from Piper are used in various sectors of the pharmaceutical, chemical and cosmetics industry (Andrade et al. 2009). However, although various Piperaceae produce essential oils in their leaves, only about $10 \%$ of Piper species have been chemically studied (Dyer et al. 2004). Piper cachimboense Yunck. (1966) has been recorded only in the Brazilian and Colombian Amazon, and the few publications about the species are restricted to distribution records (Bernal et al. 2016). Therefore, the objective of this study was to carry out the first phytochemical assessment of the composition of essential oils obtained from leaves of $P$. cachimboense.

Piper cachimboense leaves were harvested at the flowering stage (Figure 1) in the Florentino farm, in the municipality of Novo Progresso, Pará State, Brazil (706'56.31”S $55^{\circ} 24^{\prime 2} 22.19^{\prime \prime W)}$ at 210 masl, in March 2015. The species was identified and had vouchers deposited at Herbarium Tangará (TANG) of the State University of Mato Grosso, Campus of Tangará da Serra (UNEMAT/CUTS).

Samples of leaves (in triplicates of $100 \mathrm{~g}$ for fresh leaves, and of $50 \mathrm{~g}$ for dry leaves) were subjected to hydrodistillation in the Vegetable Ecophysiology Laboratory, at the Federal University of Paraná (UFPR). For the extraction of EOs from dry leaves, the materials were dried into forced air oven for 96 hours at $50{ }^{\circ} \mathrm{C}$. For all oil extraction the leaves (fresh and dry) were placed in a glass flask (2 L) containing $1 \mathrm{~L}$ of distilled water. The water was boiled for 4 hours and the oil collected in a Clevenger-type apparatus. The volume measurement of EOs extracted from leaves was determined with the assistance of precision micropipettes $(0-100 \mathrm{uL})$

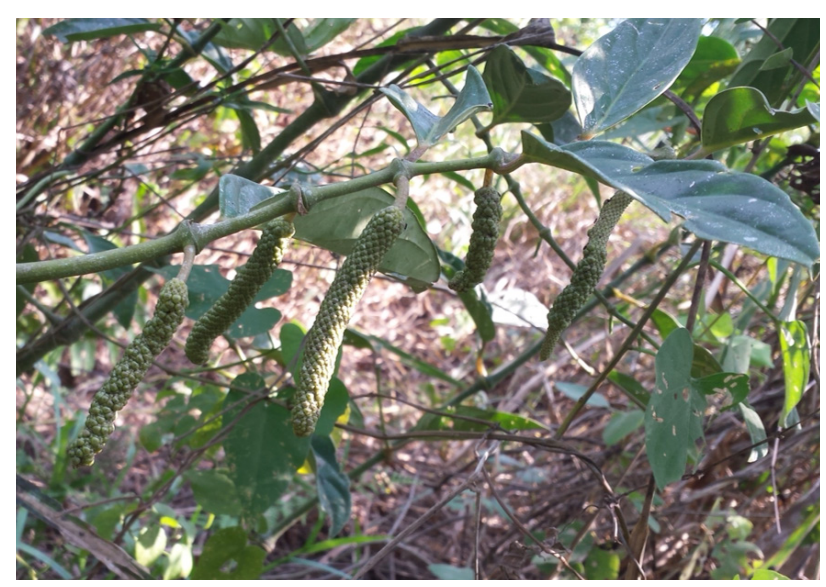

Figure 1. Plant of Piper cachimboense (Note the characteristic fruit/inflorescence of this species) Photo: D. Krinski. This figure is in color in the electronic version. and the yield was corrected to a dry basis after obtaining the constant weight of dried sub-samples in forced air oven at 65 ${ }^{\circ} \mathrm{C}$. The yield was calculated based in the dry matter (DM), which is a standardized method that can be repeated at any time, without significant deviations (Santos et al. 2004).

Chromatographic analysis was performed in the Laboratory of Vegetable Ecophysiology and Laboratory of Natural Products and Chemical Ecology (LAPEQ), both at UFPR. The EOs were subjected to analysis by gas chromatography coupled to a flame ionization detector (HPAgilent 7890A GC-FID) and by gas chromatography coupled to mass spectrometry (MS) $\left(60-240{ }^{\circ} \mathrm{C}\right.$ at $3{ }^{\circ} \mathrm{C}$ minutes rate) using a fused-silica capillary column $(30 \mathrm{~m} \times 0.25 \mathrm{~mm}$ i.d. x $0.25 \mu \mathrm{m})$ coated with DB-5. The injector and detector temperatures were $280^{\circ} \mathrm{C}$. Hydrogen was used as carrier gas at a flow rate of $2.4 \mathrm{~mL} /$ minutes; injection was in the split mode (1:20), and the injection volume was $1.0 \mu \mathrm{L}$. MS spectra were obtained using electron ionization at $70 \mathrm{eV}$ with a scan interval of 0.5 seconds and mass range from 40 to $550 \mathrm{~m} / \mathrm{z}$. The initial identification of components of the EOs was carried out by comparison with previously reported values of retention indices, obtained by co-injection of oil samples and C11-C24 linear hydrocarbons and calculated according to the equation of Van den Dool and Kratz (1963). Subsequently, the MS acquired for each component was matched with those stored in the Wiley/NBS mass spectral library of the GC-MS system and with other published mass spectral data (Adams 2007).

The yield of EOs were $11.03 \pm 5.94 \%$ for fresh leaves and $1.07 \pm 0.27 \%$ for dry leaves. The analysis showed 36 volatile compounds identified for fresh leaves and 49 for dried leaves, representing $78.62 \%$ and $82.51 \%$ of the total oil identified respectively.

According to Costa et al., (2005) the levels and chemical composition of essential oils of aromatic plants are influenced by several factors, such as the drying or not of the material used to obtain the oils. We observed in P. cachimboense a higher percentage of each compound for the oils obtained from dry leaves, although some compounds ( $\delta$-elemene, germacrene $\mathrm{D}$, asaricin, $\gamma$-cadinene, globulol, dilapiolle, apiole and methyl linoleate) showed a higher percentage yield when using fresh leaves. A possibility for this result would be that in the process of drying the leaves, not only water but also part of these compounds would be lost. But, in general terms, both oils showed some similarity in the qualitative composition (Table 1).

Some compounds often found in essential Piperaceae oils, like safrole, apiol, spathulenol and dillapiole (Scott $e t$ al. 2008) were also present in P. cachimboense, as well as in other Piper species (e.g. Santos et al. 2001; Andrade et al. 2009; Cruz et al. 2011). These compounds are of economic interest. For example, safrole is the raw material for the synthesis of piperonal, which is used in the composition of perfumes (Barbosa et al. 2012). Besides the industrial 
importance of its essential oils, Piper species have been used for many centuries in the traditional medicine for different purposes and many activities (Ghosh et al. 2014). Our data reinforce the accumulated knowledge that Piper species in general have a notable tendency to biosynthesize essential oils, independently of their natural habitats (Santos et al. 2001). This first report on the chemical composition of the essential oil of $P$. cachimboense shows that the phytochemical potential of many Piper species is still untapped.
Other studies are necessary to assess the seasonal effect on the overall yield, and the amount of major compounds of the essential oil of $P$. cachimboense. Considering that the leaves of $P$. cachimboense are easily harvested, the species is a good candidate for bioactivity testing of its oils regarding pest control in its occurrence region (Krinski 2013; Krinski 2015; Krinski et al. 2015; Krinski and Foerster 2017), as already known for other Piperaceae species (Krinski and Foerster 2016; Turchen et al. 2016; Sanini et al. 2017).

Table 1. Phytochemical composition of fresh and dried leaves of Piper cachimboense sampled at Novo Progresso, Pará State, Brazil. Rlc= retention index calculeted; Rl= retention index tabulated (Adams 2007). Numbers for the relative area of leaves are means followed by the standard deviation.

\begin{tabular}{|c|c|c|c|c|}
\hline \multirow{2}{*}{ Compounds identified } & \multicolumn{2}{|c|}{ Retention Index } & \multicolumn{2}{|c|}{ Relative area (\%) } \\
\hline & $\mathrm{Rl}^{\mathrm{c}}$ & $\mathrm{Rl}^{\mathrm{t}}$ & Fresh leaves & Dried leaves \\
\hline 1) a-pinene & 932 & 932 & $0.06 \pm 0.07$ & $0.14 \pm 0.06$ \\
\hline 2) a-terpinene & 1014 & 1015 & - & $0.72 \pm 0.17$ \\
\hline 3) p-cimene & 1022 & 1022 & - & $0.67 \pm 0.15$ \\
\hline 4) limonene & 1024 & 1026 & - & $0.12 \pm 0.04$ \\
\hline 5) $\gamma$-terpinene & 1054 & 1056 & - & $1.90 \pm 0.35$ \\
\hline 6) terpinolene & 1086 & 1087 & - & $0.46 \pm 0.08$ \\
\hline 7) linalol & 1095 & 1100 & - & $0.16 \pm 0.03$ \\
\hline 8) terpinen-4-ol & 1174 & 1174 & - & $0.12 \pm 0.01$ \\
\hline 9) piperitone & 1249 & 1250 & - & $0.20 \pm 0.01$ \\
\hline 10) safrole & 1285 & 1284 & $0.27 \pm 0.10$ & $0.92 \pm 0.14$ \\
\hline 11) $\delta$-elemene & 1335 & 1334 & $0.94 \pm 0.10$ & $0.52 \pm 0.03$ \\
\hline 12) a-cubebene & 1345 & 1346 & $0.19 \pm 0.05$ & $0.31 \pm 0.03$ \\
\hline 13) a-copaene & 1374 & 1371 & $0.85 \pm 0.12$ & $2.00 \pm 0.15$ \\
\hline 14) $\beta$-elemene & 1389 & 1388 & $1.08 \pm 0.06$ & $1.10 \pm 0.03$ \\
\hline 15) a-gurjunene & 1409 & 1403 & - & $0.17 \pm 0.01$ \\
\hline 16) (E)-caryophyllene & 1417 & 1413 & $4.65 \pm 0.58$ & $7.46 \pm 0.39$ \\
\hline 17) $\beta$-gurjunene & 1431 & 1423 & $0.63 \pm 0.07$ & $0.89 \pm 0.03$ \\
\hline 18) aromadendrene & 1439 & 1432 & $0.64 \pm 0.09$ & $1.39 \pm 0.04$ \\
\hline 19) 6,9-guiadiene & 1442 & 1437 & $0.13 \pm 0.03$ & $0.17 \pm 0.00$ \\
\hline 20) a-humulene & 1452 & 1446 & $1.34 \pm 0.06$ & $1.78 \pm 0.06$ \\
\hline 21) cis-cadina-1(6),9-diene & 1461 & 1452 & $1.00 \pm 0.11$ & $1.59 \pm 0.05$ \\
\hline 22) y-muurolene & 1478 & 1472 & - & $3.98 \pm 0.04$ \\
\hline 23) germacrene $D$ & 1480 & 1475 & $27.64 \pm 2.29$ & $6.31 \pm 0.20$ \\
\hline 24) $\beta$-selinene & 1489 & 1479 & $0.23 \pm 0.01$ & $1.92 \pm 0.07$ \\
\hline 25) $\gamma$-amorfene & 1495 & 1490 & $6.57 \pm 0.98$ & $6.88 \pm 0.12$ \\
\hline 26) a-muurolene & 1500 & 1493 & - & $1.53 \pm 0.07$ \\
\hline 27) asaricin & 1495 & 1495 & $1.93 \pm 0.08$ & $1.51 \pm 0.02$ \\
\hline 28) $\beta$-bisabolene & 1505 & 1502 & $0.70 \pm 0.16$ & $0.45 \pm 0.02$ \\
\hline 29) $y$-cadinene & 1513 & 1508 & $3.10 \pm 0.22$ & $2.65 \pm 0.03$ \\
\hline 30) $\delta$-cadinene & 1522 & 1519 & $6.19 \pm 0.16$ & $9.20 \pm 0.04$ \\
\hline 31) trans-cadina-1,4-diene & 1533 & 1526 & $0.62 \pm 0.05$ & $0.82 \pm 0.02$ \\
\hline 32) a-cadinene & 1537 & 1532 & $0.58 \pm 0.03$ & $0.59 \pm 0.01$ \\
\hline 33) a-calacorene & 1544 & 1536 & $0.19 \pm 0.03$ & $0.68 \pm 0.01$ \\
\hline 34) elemicin & 1555 & 1558 & $0.31 \pm 0.04$ & $0.93 \pm 0.02$ \\
\hline 35) (E)-nerolidol & 1561 & 1562 & $2.54 \pm 0.94$ & $3.37 \pm 0.04$ \\
\hline 36) spathulenol & 1577 & 1570 & $0.87 \pm 0.06$ & $4.65 \pm 0.24$ \\
\hline
\end{tabular}


Table 1. Continued.

\begin{tabular}{|c|c|c|c|c|}
\hline \multirow{2}{*}{ Compounds identified } & \multicolumn{2}{|c|}{ Retention Index } & \multicolumn{2}{|c|}{ Relative area (\%) } \\
\hline & $\mathrm{Rl}^{\mathrm{c}}$ & $\mathrm{RI}^{\mathrm{t}}$ & Fresh leaves & Dried leaves \\
\hline 37) caryophyllene oxide & 1582 & 1574 & $2.13 \pm 0.33$ & $3.50 \pm 0.09$ \\
\hline 38) globulol & 1590 & 1583 & $0.44 \pm 0.08$ & $0.29 \pm 0.01$ \\
\hline 39) guaiol & 1600 & 1585 & $0.54 \pm 0.06$ & $0.49 \pm 0.02$ \\
\hline 40) rosifoliol & 1600 & 1594 & $0.60 \pm 0.05$ & $0.71 \pm 0.03$ \\
\hline 41) humulene epoxide II & 1608 & 1599 & $0.17 \pm 0.07$ & $0.67 \pm 0.03$ \\
\hline 42) 10-epi-y-eudesmol & 1622 & 1604 & $0.42 \pm 0.09$ & $0.46 \pm 0.03$ \\
\hline 43) dilapiolle & 1620 & 1607 & $1.29 \pm 0.17$ & $0.79 \pm 0.03$ \\
\hline 44) epi-a-muurolol & 1640 & 1622 & $1.41 \pm 0.14$ & $2.85 \pm 0.19$ \\
\hline 45) cubenol & 1645 & 1627 & - & $0.16 \pm 0.01$ \\
\hline 46) a-cadinol & 1652 & 1631 & - & $0.24 \pm 0.03$ \\
\hline 47) apiole & 1677 & 1647 & $5.68 \pm 0.66$ & $3.05 \pm 0.26$ \\
\hline 48) $(E, Z)$-linalol de garnil & 1987 & 2025 & $0.23 \pm 0.11$ & $0.49 \pm 0.04$ \\
\hline 49) methyl linoleate & 2095 & 2081 & $2.42 \pm 0.23$ & $0.54 \pm 0.05$ \\
\hline Total & & & 78.62 & 82.51 \\
\hline
\end{tabular}

\section{ACKNOWLEDGEMENTS}

The authors acknowledge the Coordenação de Aperfeiçoamento de Pessoal de Nível Superior (CAPES) for providing a scholarship to the first author, Dr. Micheline Carvalho-Silva, at Universidade Federal dos Vales do Jequitinhonha e Mucuri (UFVJM), for the identification of Piper cachimboense, and Dr. Beatriz Helena Noronha Sales Maia, of the Department of Chemistry at Universidade Federal do Paraná (UFPR) and the entire staff of the Laboratory of Natural Products and Chemical Ecology (LAPEQ/UFPR) for the chromatography analysis and help in the identification of chemical compounds.

\section{REFERENCES}

Adams, R.P. 2007. Identification of Essential Oil Components by Gas Chromatography/Quadrupole Mass Spectroscopy. Allured Publishing Corporation, Carol Stream, USA, 804p.

Andrade, E.H.A.; Guimarães, E.F.; Maia, J.G.S. 2009. Variabilidade química em óleos essenciais de espécies de Piper da Amazônia. FEQ/ UFPA, Belém, 448p.

Barbosa, Q.P.S.; Câmara, C.A.G.; Ramos, C.S.; Nascimento, D.C.O.; Lima-Filho, J.V.; Guimarães, E.F. 2012. Chemical composition, circadian rhythm and antibacterial activity of essential oils of Piper divaricatum: a new source of safrole. Quimica Nova, 35: 1806-1808.

Bernal, R.; Gradstein, S.R.; Celis, M. 2016. Catálogo de plantas y liquenes de Colombia. 1.ed. Instituto de Ciencias Naturales, Universidad Nacional de Colombia, Bogotá. (http://catalogoplantasdecolombia.unal.edu.co). Accessed on 25/09/2017.

Costa, L.C.B.; Corrêa, R.M.; Cardoso, J.C.W.; Pinto, J.E.B.P.; Bertolucci, S.K.V.; Ferri, P.H. 2005. Secagem e fragmentação da matéria seca no rendimento e composição do óleo essencial de capim-limão. Horticultura Brasileira, 23: 956-959.
Cruz, S.M.; Cáceres, A.; Álvarez, L.E.; Apel, M.A.; Henriques, A.T. 2011. Chemical diversity of essential oils of 15 Piper species from Guatemala. Acta Horticulturae, 964: 39-46.

Dyer, L.A. 2004. Isolation, Synthesis, and Evolutionary Ecology of Piper Amides, In: Dyer, L.A.; Palmer, A.N.D. (eds.) Piper: A model genus for studies of Phytochemistry, Ecology and Evolution. Kluwer Academic/Plenum Publishers, New York. p.117-139.

Ghosh, R.; Darin, K.; Nath, P.; Deb, P. 2014. An overview of various Piper species for their biological activities. International Journal of Pharma Research \& Review, 3: 67-75.

Guimarães, E.F.; Carvalho-Silva, M. 2012. Piperaceae In: Wanderley, M.G.L., Martins, S.E., Romanini, R.P., Melhem, T.S., Shepherd, G.J., Giulietii, A.M., Pirani, J.R., Kirizawa, M., Melo, M.M.R.F., Cordeiro, I., Kinoshita, L.S. (Ed.). Flora Fanerogâmica do Estado de São Paulo. v.7. Instituto de Botânica, São Paulo, p.263-320.

Krinski, D. 2013. First report of phytophagous stink bug in chicory crop. Ciência Rural, 43: 42-44.

Krinski, D. 2015. First report of Squash Vine Borer, Melittia cucurbitae (Harris, 1828) (Lepidoptera, Sessidae) in Brazil and South America: distribution extension and geographic distribution map. Check List, 11: 1-3.

Krinski, D.; Foerster, L.A. 2016. Toxicity of essential oils from leaves of five Piperaceae species in rice stalk stink bug eggs, Tibraca limbativentris (Hemiptera: Pentatomidae). Ciência e Agrotecnologia, 40: 676-687.

Krinski, D.; Foerster, L.A. 2017. Damage by Tibraca Limbativentris Stål (Pentatomidae) to upland rice cultivated in Amazon Rainforest region (Brazil) at different growth stages. Neotropical Entomology, 46: 107-114.

Krinski, D.; Foerster, L.A.; Grazia, J. 2015. Hypatropis inermis (Hemiptera, Pentatomidae): first record on rice crops. Revista Brasileira de Entomologia, 59: 12-13. 
Monteiro, D.; Guimarães, E.F. 2009. Flora do Parque Nacional do Itatiaia-Brasil: Manekia e Piper (Piperaceae). Rodriguésia, 60: 999-1024.

Sanini, S.; Massaroli, A.; Krinski, D.; Butnariu, A.R. 2017. Essential oil of spiked pepper, Piper aduncum L. (Piperaceae) for the control of caterpillar soybean looper, Chrysodeixis includens Walker (Lepidoptera). Brazilian Journal of Botany, 40, 399-404.

Santos, A.S.; Alves, S.M.; Baker, D.; Rocha-Neto, O. 2004. Descrição de sistema e métodos de extração de óleos essenciais e determinação de umidade de biomassa em laboratório. Embrapa Amazônia Oriental, Belém, 6p.

Santos, P.R.D.; Moreira, D.L.; Guimarães, E.F.; Kaplan, M.A. 2001. Essential oil analysis of 10 Piperaceae species from the Brazilian Atlantic forest. Phytochemistry, 58: 547-551.

Scott, I.M.; Jensen, H.R.; Philogène, B.J.R.; Arnason, J.T. 2008. A review of Piper spp. (Piperaceae) phytochemistry, insecticidal activity and mode of action. Phytochemistry Reviews, 7: 65-75.
Turchen, L.M.; Piton, L.P.; Dall'Oglio, E.L.; Butnariu, A.R.; Pereira, M.J. 2016. Toxicity of Piper aduncum (Piperaceae) essential oil against Euschistus heros (F.) (Hemiptera: Pentatomidae) and noneffect on egg parasitoids. Neotropical Entomology, 45: 604-611.

Van den Dool H.; Kratz, P.D. 1963. A generalization of the retention index system including liner temperature programmed gasliquid partition chromatography. Journal of Chromatography A, 11: 463-467.

RECEIVED: $28 / 09 / 2017$

ACCEPTED: 03/10/2017

ASSOCIATE EDITOR: João Vicente Braga Souza 